ZOOLOGIA 28 (2): 193-198, April, 2011

doi: $10.1590 /$ S1984-46702011000200006

\title{
Feeding habits of Molina's hog-nosed skunk, Conepatus chinga (Carnivora: Mephitidae) in the extreme south of Brazil
}

\author{
Felipe Bortolotto Peters; Paulo Ricardo de Oliveira Roth \& Alexandre Uarth Christoff
}

Departamento de Biologia, Museu de Ciências Naturais, Universidade Luterana do Brasil. Avenida Farroupilha 8001, 92425-900 Canoas, RS, Brasil.E-mail: felipe.peters@areadevida.com.br

\begin{abstract}
Feeding habits of the Molina's hog-nosed skunk, Conepatus chinga (Molina, 1782) in the extreme south of Brazil. We analyzed 60 stomachs of road-kills of C. chinga in the extreme south of Brazil. The contents revealed 808 prey parts, including invertebrates (frequency of occurrence - FO $=96.7 \%$ and relative abundance - RA $=94.7 \%$ ), vertebrates $(\mathrm{FO}=18.3 \%$ and $\mathrm{RA}=2.8 \%$ ) and plants $(\mathrm{FO}=31.7 \%$ and $\mathrm{RA}=2.3 \%)$. We identified 18 kinds of food, including the invertebrate order Coleoptera which showed the highest FO (86.7\%) and RA (75.2\%). Other important orders were Orthoptera ( $F=35 \%$ and $\mathrm{RA}=10.4 \%)$ and Araneae $(\mathrm{FO}=41.7 \%$ and $\mathrm{RA}=4 \%)$. The combination of occurrence and abundance of the preys consumed allowed classifying C. chinga as an omnivorous with a predominance of insects, especially Coleoptera, consuming other invertebrates, vertebrates and plants in smaller numbers. Behavioral and morphological adaptations of $C$. chinga favor the predation of insects, which are preys that offer low physical resistance and are available in all terrestrial environments.
\end{abstract}

KEY WORDS. Diet; omnivorous; Pampa; predator; road-kill fauna.

Conepatus Gray, 1973 comprises four species (WozEnCRAFT 2005), which are popularly known as skunks and distributed from the north of the United States to southern Argentina and Chile (van GeLder 1968). Two species occur in Brazil: Conepatus semistriatus (Boddaert, 1785) which is restricted to the Caatinga, Cerrado and Pantanal biomes (Borges \& TOMAs 2004, Cheida et al. 2006); and Conepatus chinga (Molina, 1782), which has occurrences in the Pampa and Atlantic Forest biomes (De Vivo \& Gregorin 2001, Cimardi 1996, Cáceres 2004). Conepatus chinga is very common in the extreme south of Brazil, where it is usually associated with landscapes composed of grasslands intercalated with forest islands and riparian forests.

The imminent loss of habitat resulting from agricultural activities and livestock (Donadio et al. 2004) and road-kills due to improper planning of roads in the Pampas (Rosa \& MAUHS 2004, Tumeleiro et al. 2006) seem to pose considerable threats to the conservation of $C$. chinga. Although this species is not included in the red lists of threatened species (INDRUSIAK \& EIZIRIK 2003, Chiarello et al. 2008, IUCN 2010), the lack of studies on its ecology, distribution and current status of conservation in Brazil and Uruguay is noteworthy.

Regarding their feeding habits, skunks prey upon a wide variety of species (Brazil 1924, Silva 1994, Cimardi 1996, EIsEnberg \& Redford 1999, Díaz \& Barquez 2002, Parera 2002, Cheida et al. 2006, Gonçalves et al. 2007, Montalvo et al. 2008). However, only Travaini et al. (1998) and Donadio et al. (2004) quantified the diet of $C$. chinga in studies carried out in Argentina. Information on its diet is absent for the Brazilian territory.
Studies of carnivore diets are essential to understand their behavior and interactions with other species, supplying data for making decisions about conservation and about management of their populations. Thus, the present study aimed to investigate the trophic niche, and to identify the most important prey in the diet of $C$. chinga from a sample of road-kill specimens from southern Brazil.

\section{MATERIAL AND METHODS}

The study area is located at the extreme south of Brazil, in the state of Rio Grande do Sul. The sampled area is located in the biogeographic region of the Pampas (CABRERA \& WiLLINK 1980) within a polygon delimited by the following geographic coordinates: $29^{\circ} 41^{\prime} \mathrm{S}-53^{\circ} 47^{\prime} \mathrm{W}, 2^{\circ} 48^{\prime} \mathrm{S}-56^{\circ} 56^{\prime} \mathrm{W}, 29^{\circ} 54^{\prime} \mathrm{S}-50^{\circ} 18^{\prime} \mathrm{W}$, $32^{\circ} 32^{\prime} \mathrm{S}-53^{\circ} 22^{\prime} \mathrm{W}$ (Fig. 1). The topography of the area varies from lowlands at sea level to plateaus at $500 \mathrm{~m}$ asl (IBGE 2006). The prevailing climate fits within the Cfa type following Koeppen's classification system with an average annual temperature varying between $10 \mathrm{C}^{\circ}$ and $15 \mathrm{C}^{\circ}$ (IBGE 1978). Physionomically, the area shows charecteristics of a seasonal steppe, with a predominance of of gramineous-herbaceous steppe, with few wooded elements and a lightly undulated smooth relief (LeiTe 2002).

To the southeast of the Rio Grande do Sul shield (sensu Carraro \& MEXIas 2002) the relief becomes undulated to strongly undulated with the occurrence of sparse perennial-leaved bushy-arboreal elements over a cespitous herbaceous-graminoid stratum and a perennial-leaved bushy xerophytic stratum. 


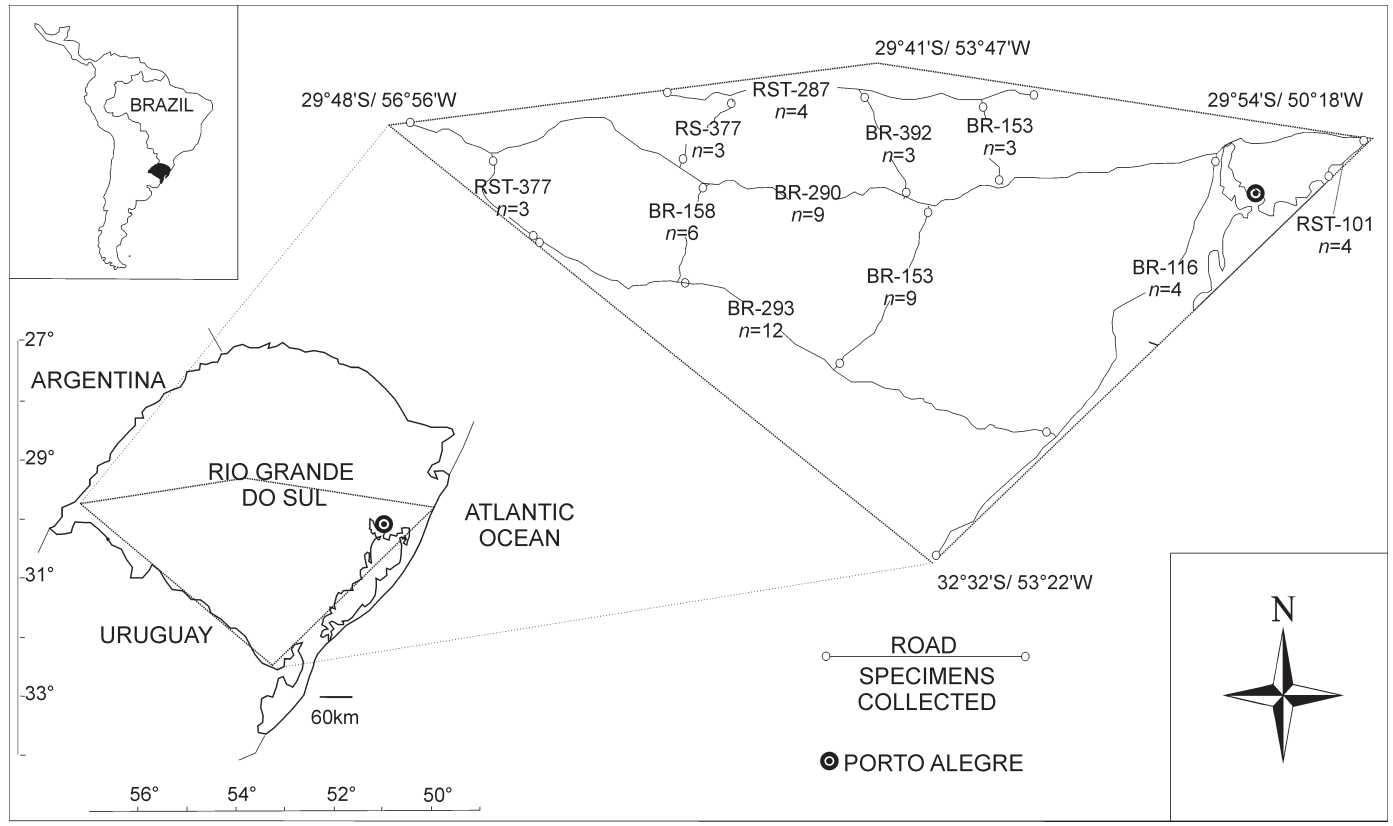

Figure 1. Location of the study area, sampled roads and number of specimens collected per road.

Along the $30^{\circ} \mathrm{S}$ latitude there are areas of Seasonal Deciduous Forest (sensu LeITE 2002) structured into four strata: bushy; with small trees; dense with trees of uniform height and discontinuous with tall trees where more than $50 \%$ are deciduous. At the eastern border of the state of Rio Grande do Sul, there is a forest classified as Seasonal Moderately Semideciduous (LeITE 2002) whose superior stratum harbors species from both the Seasonal Deciduous and Atlantic Rain Forests, where between 20 and $50 \%$ of the trees in the upper stratum are deciduous. The study area also includes the Coastal Plain composed by herbaceous, gramineous and subarbustive strata in dunes and floodable areas, which is constantly under fluviomarine and strong wind influence (Leite 2002, Quadros \& Pillar 2002).

Among the economic activities that threaten the biodiversity of the region under study, the agriculture and livestock industry stand out (Overbeck et al. 2007) by altering originally forested areas and by using natural fields. Likewise, plantations of exotic trees have been replacing areas of native vegetation within the study area, especially in the coastal plain and in Rio Grande do Sul shield (IBGE 2004). This activity is, at the present moment, under strong expansion and already occupies 400.000 ha of the Rio Grande do Sul state territory (SBS 2007, Overbeck et al. 2007).

We collected 60 roadkill specimens from November 2005 to March 2007. Their stomachs were removed, fixed in formaldehyde $10 \%$, and then preserved in alcohol 70\%.

We used a stereomicroscope to identify and separate prey parts, as well as to determine the minimum number of specimens ingested. Plant parts were considered as a single food item category due to the lack of fruit fragments, seeds and roots that precluded finer identification. Invertebrates were separated by counting mouthparts and cephalic capsules, whereas for vertebrates we considered mandibles, teeth, beaks and other bone fragments.

The contents were first divided into three categories: plants, invertebrates and vertebrates, and then subsequently identified, when possible, to the species level. Differences in the abundance of prey categories in relation to seasonality were verified with Mann-Whitney's U-test (ZAR 1999) from the grouping of stomachs collected in autumn $(n=25)$, winter $(n=26)$, spring $(n=4)$ and summer $(n=5)$.

In order to quantify the contribution of each alimentary category to the diet of $C$. chinga, we used two indexes: relative abundance (RA), which determines the number and the percentage of each item in the sample; and frequency of occurrence (FO), which expresses the percentage of stomachs that contained a given prey item.

We defined the most important food items by the combination of these two indexes, using a graphical representation that follows the adaptation proposed by Costello (1990), with FO values on the $\mathrm{y}$-axis and RA values on the $\mathrm{x}$-axis. A dot located next to $100 \%$ occurrence and $100 \%$ abundance represents the dominant prey item. A group of dots located next to $100 \%$ occurrence and 1\% abundance indicates that the predator consumed different preys in low quantity, and therefore is considered a trophic generalist. In contrast, dots located next to $1 \%$ occurrence and $100 \%$ abundance show that the predator is a specialist in a given prey item. 


\section{RESULTS}

We counted 808 prey parts classified into 18 categories of food, including plants, invertebrates and vertebrates. The average number of individual prey per stomach sample was $13.46 \pm 3.05 \mathrm{SD}$ (Tab. I). With these results it is possible to evaluate the contribution of each food resource to the diet of C. chinga, indicating invertebrates as the dominant prey item (Fig. 2). When seasons were compared, there was no significant difference in the abundance of ingested prey $(\mathrm{p}>0.05)$. Invertebrates were the dominant prey regardless of the season (Tab. II).

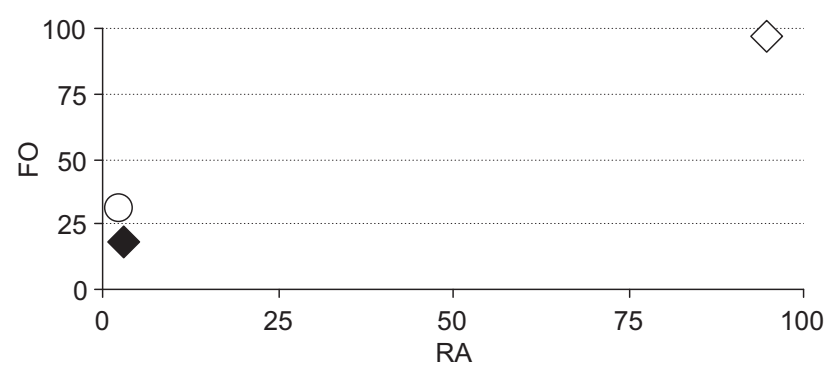

Figure 2. Graphic representation of the results obtained with the analysis of occurrence (FO) and abundance (RA) for invertebrates $(\diamond)$, vertebrates $(\diamond)$ and plants $(\bigcirc)$.

The order Coleoptera exhibited the highest frequency of occurrence and abundance among all preyed taxa. Although adults and larvae of Scarabaeidae and Carabidae were identified, it was not possible to identify them to species level. Other invertebrates from the orders Araneae and Orthoptera exhibited high occurrences, however, their percentages of abundance were small.

The order Rodentia represented the main vertebrates consumed, even though they appear as occasional preys. The predation of Mus musculus Linnaeus, 1758 was overestimated due to the occurence of one adult and ten newborns preyed by a single of Molina's hog-nosed skunk. The plants found represent the order Poales. Although present in almost one third of the samples, they exhibited a very low abundance. It is possible that the ingestion of Poales occurs accidentally during foraging in the soil.

\section{DISCUSSION}

The combination of occurrence and abundance of the prey items consumed as a dietary resource allowed classifying C. chinga as an omnivorous, with a predominance of insects, especially of the order Coleoptera, and with the presence of other invertebrates, vertebrates and plants in minor proportions.
Table I. Food items used by $C$. chinga in the extreme south of Brazil. Relative abundance (RA) and frequency of occurrence (FO) of prey items in 60 stomachs ( $\mathrm{n}$ : numbers of itens; \%: percentage).

\begin{tabular}{|c|c|c|c|c|}
\hline \multirow{2}{*}{ Taxon } & \multicolumn{2}{|c|}{ RA } & \multicolumn{2}{|r|}{ FO } \\
\hline & $\mathrm{n}$ & $\%$ & $\mathrm{n}$ & $\%$ \\
\hline \multicolumn{5}{|l|}{ Invertebrates } \\
\hline \multicolumn{5}{|l|}{ Arachnida } \\
\hline Araneae & 32 & 4.0 & 25 & 41.7 \\
\hline Scorpiones & 6 & 0.7 & 6 & 10.0 \\
\hline Diplopoda & 1 & 0.1 & 1 & 1.7 \\
\hline Chilopoda & 2 & 0.2 & 2 & 3.3 \\
\hline \multicolumn{5}{|l|}{ Insecta } \\
\hline Coleoptera & 608 & 75.2 & 52 & 86.7 \\
\hline Diptera & 1 & 0.1 & 1 & 1.7 \\
\hline \multicolumn{5}{|l|}{ Hymenoptera } \\
\hline Formicidae & 11 & 1.4 & 6 & 10.0 \\
\hline Lepidoptera & 20 & 2.5 & 8 & 13.3 \\
\hline Orthoptera & 84 & 10.4 & 21 & 35.0 \\
\hline Subtotal of invertebrates & 765 & 94.7 & 58 & 96.7 \\
\hline \multicolumn{5}{|l|}{ Vertebrates } \\
\hline \multicolumn{5}{|l|}{ Amphibia } \\
\hline Anura & 4 & 0.5 & 4 & 6.7 \\
\hline \multicolumn{5}{|l|}{ Reptilia } \\
\hline \multicolumn{5}{|l|}{ Testudinata (Egg) } \\
\hline $\begin{array}{l}\text { Trachemys dorbigni (Duméril } \\
\text { \& Bibron, 1835) }\end{array}$ & 1 & 0.1 & 1 & 1.7 \\
\hline Squamata & 1 & 0.1 & 1 & 1.7 \\
\hline Aves & 1 & 0.1 & 1 & 1.7 \\
\hline \multicolumn{5}{|l|}{ Mammalia } \\
\hline \multicolumn{5}{|l|}{ Rodentia } \\
\hline Mus musculus Linnaeus, 1758 & 13 & 1.6 & 3 & 5.0 \\
\hline Oligoryzomys Bangs, 1900 & 2 & 0.2 & 2 & 3.3 \\
\hline $\begin{array}{l}\text { Holochilus brasiliensis } \\
\text { (Desmarest, 1819) }\end{array}$ & 1 & 0.1 & 1 & 1.7 \\
\hline $\begin{array}{l}\text { Calomys laucha (G. Fischer, } \\
\text { 1814) }\end{array}$ & 1 & 0.1 & 1 & 1.7 \\
\hline Subtotal of vertebrates & 24 & 2.8 & 11 & 18.3 \\
\hline \multicolumn{5}{|l|}{ Plants } \\
\hline \multicolumn{5}{|l|}{ Magnoliopsida } \\
\hline \multicolumn{5}{|l|}{ Cyperales } \\
\hline Poaceae & 19 & 2.3 & 19 & 31.7 \\
\hline Subtotal of plants & 19 & 2.3 & 19 & 31.7 \\
\hline Total & 808 & 100 & 60 & 100 \\
\hline
\end{tabular}




\begin{tabular}{|c|c|c|c|c|c|c|c|c|c|c|c|c|}
\hline & \multicolumn{2}{|c|}{$\mathrm{W} \times \mathrm{Su}$} & \multicolumn{2}{|c|}{$W \times S p$} & \multicolumn{2}{|c|}{$W \times A$} & \multicolumn{2}{|c|}{ Su $\times$ Sp } & \multicolumn{2}{|c|}{ Su $\times A$} & \multicolumn{2}{|c|}{$S p \times A$} \\
\hline & $U$ & $p$ & $U$ & $p$ & $U$ & $p$ & $U$ & $p$ & $U$ & $p$ & $\mathrm{U}$ & $p$ \\
\hline Invertebrates & 58 & 0.70 & 33 & 0.24 & 238 & 0.10 & 4.5 & 0.17 & 34.0 & 0.11 & 43.5 & 0.68 \\
\hline Vertebrates & 64 & 0.98 & 50 & 0.90 & 310 & 0.78 & 9.5 & 0.90 & 60.0 & 0.88 & 45.5 & 0.77 \\
\hline Plants & 51 & 0.45 & 45 & 0.66 & 265 & 0.25 & 6.5 & 0.39 & 37.5 & 0.16 & 47.5 & 0.87 \\
\hline
\end{tabular}

The large number of Coleoptera, along with the lack of seasonality in prey consumption inferred during this study, corroborates the studies of Donadio et al. (2004), who noted that Molina's hog-nosed skunk, prefers to prey upon beetles in comparison with other invertebrates, even in areas where or periods when the beetles are not abundant. 'The lack of studies about Coleoptera at the study area (Moura 2003, SiLva et al. 2008) prevented associations between the frequency/abundance of beetles preyed with their population fluctuations and local diversity. However, there was a predominance of Coleoptera over the other invertebrates preyed independently of seasonality. Donadio et al. (2001) mentioned that skunks exhibit behavioral and morphological adaptations that favor the location and capture of organisms with fossorial and cryptozoic habits. Strong anterior paws and claws, as well as the prominent muzzle are used for excavation and localization of prey, which is a strategy that allows $C$. chinga to consume these organisms throughout the year.

The relationship between carnivore tooth morphology and feeding habits has been established in many studies (van Valkenburgh 1991, Popowics 2003, Sacco \& van Valkenburgh 2004, FRISCIA et al. 2006), making an important argument to explain the low quantity of vertebrates used as a food resource by the Molina's hog nosed skunk.' Carnivores, which are mostly vertebrate predators, have their teeth adapted to kill and lacerate tissues, carnassial teeth with long blades (trigonid) and reduced crushing surface (talonid) (SACCO \& VAN VALKENBURGH 2004, FrisCIA et al. 2006) as seen in Puma yagouaroundi (É. Geoffroy SaintHilaire, 1803), Galictis cuja (Molina, 1782) and species of Leopardus Gray, 1842, which are sympatric with C. chinga. Regarding the teeth and skull anatomy,, Lycalopex gymnocercus (G. Fischer, 1814), Cerdocyon thous (Linnaeus, 1766), Procyon cancrivorus (G. [Baron] Cuvier, 1798) and Conepatus chinga have contrasting characteristics: small blades, long crushing suface, and enlargement of the post-carnassial molar. These dentition characteristics are conspicuous in skunks and are found in carnivores with morphological adaptations favorable to omnivorous diets. The grinding function of the carnassial apparatus in skunks (VAUghan et al. 1999) is considered to be appropriate for a diet with a predominance of beetles: small prey that offer lower physical resistance.

Many Coleoptera are considered agricultural pests and are related to environmental distrurbance resulting from long droughts and from the increase in cultivated areas (LINK \& CosTA 1984, CunHa et al. 2007). This apparent abundance of food resources may favor an increase in the population of Molina's hog-nosed skunks within the area, which could explain the large amount of road-kills of this species in the Pampa biome. The effect of pesticide use, associated with agriculture, is correlated with the decline of the American hog-nosed skunk, $C$. leuconotus (Lichtenstein, 1832), population in North America, during the last decades (Dragoo et al. 2003). Considering the indiscriminate use of agricultural pesticides in the Pampas landscape, the populations of $C$. chinga could be affected in the future. In the Pampas landscape, the environmental impacts inflicted upon the agroecosystems justifies the need to carry out further studies on the conservation of Molina's hog-nosed skunk, aiming at questions such as the impact of roads, the increase in agricultural areas, the plasticity in habitat use, and the long term viability of their populations.

\section{ACKNOWLEDGMENTS}

We thank Área de Vida for the financial support of most field expeditions. We also thank the reviewers; the colleagues from Pelotas Fabio D. Mazim, Aguinaldo D. Piske, Felipe Garcias; the colleagues from the ULBRA Natural Science Museum Diego M. Jung, Eduardo Coelho and Leonardo F. Machado; and especially Sabrina Milchareck, for helping in the field, and Gelson Fiorentin and Nora Fortes for their support in the lab. We thank the staff from UFRGS Herpetological laboratory for helping with the prey identification and Renato M. Peters for the collected specimens.

\section{LITERATURE CITED}

Borges, P.A.L. \& W.M. Tomas. 2004. Guia de Rastros e Outros Vestígios de Mamíferos do Pantanal. Corumbá, Embrapa Pantanal, 139p.

BraziL, V. 1924. Notas sobre a biologia de Conepatus chilensis contribuição ao estudo de seu aparelho defensivo. Arquivos do Instituto Vital Brazil 2 (2): 57-67.

Cabrera, A. \& A. Willink. 1980. Biogeografia de America Latina. Washington, D.C., OEA, $2^{\text {nd }}$ ed., 117p.

CÁCERES, N.C. 2004. Ocurrence of Conepatus chinga (Molina) (Mammalia, Carnivora, Mustelidae) and other terrestrial 
mammals in the Serra do Mar, Paraná, Brazil. Revista Brasileira de Zoologia 21 (3): 577-579.

Carraro, C.C. \& A.S. Mexias. 2002. Imagens de Sensoriamento Remoto no Mapeamento de Lineamentos do Centro do Escudo Sul-Rio-Grandense, p. 1757-1764. In: Anais do XII Simpósio Brasileiro de Sensoriamento Remoto. Goiânia, Available online at: http://marte.dpi.inpe.br/col/ltid.inpe.br/ sbsr/2004/11.21.11.09/doc/1757.pdf [Accessed: 04/II/2010].

Cheida, C.C.; E. Nakano-Oliveira; R. Fusco-Costa; F. Rocha-MenDES \& J. Quadros. 2006. Ordem Carnívora, p. 231-266. In: N.R. Reis; A.L. Peracchi; W.A. Pedro; I.P. Lima (Eds). Mamíferos do Brasil. Londrina, UEL, 437p.

Chiarello, A.G.; L.M.S. Aguiar; R. Cerqueira; F.R. Melo; F.H.G. Rodrigues \& V.M.F. Silva. 2008. Mamíferos, p. 680-874. In: A.B.N.Machado; G.M. Drummond \& A.P. Paglia (Eds). Livro vermelho da fauna brasileira ameaçada de extinção. Belo Horizonte, MMA, Fundação Biodiversitas, 1420p.

Cimardi, A.V. 1996. Mamíferos de Santa Catarina. Florianópolis, FATMA, 302p.

Costello, M.J. 1990. Predator feeding strategy and prey importance: a new graphical analysis. Journal of Fish Biology 36: 261-263.

Cunha, U.S.; A.D. Grützmacher; J.F.S. Martins; G.J. Stefanello \& E.O. JARDIM. 2007. Ocorrência de Euphoria lurida (Fabricius) (Coleoptera: Scarabaeidae) em milho cultivado em várzea no Rio Grande do Sul. Neotropical Entomology 36 (6): 976979.

De Vivo, M. \& R. Gregorin. 2001. Mamíferos, p. 116-123. In: C. LeONel (Ed). Intervales. São Paulo, Fundação para a Conservação e a Produção Florestal do Estado de São Paulo, IX+240p.

Díaz, M.M. \& R.M. BARQuez. 2002. Los mamíferos de Jujuy. Buenos Aires, LOLA, 326p.

Donadio, E.; S. Di Martino; M. Aubone \& A.J. Novaro. 2001. Activity patterns, home range, and habitat selection of the common hog-nosed skunk, Conepatus chinga (Mammalia, Mustelidae), in northwestern Patagonia. Mammalia 65 (1): 49-54.

Donadio, E.; S. Di Martino; M. Aubone \& A.J. Novaro. 2004. Feeding ecology of the Andean hog-nosed skunk (Conepatus chinga) in areas under different land use in north-western Patagonia. Journal of Arid Environments 56 (4): 709-718.

Dragoo, J.W.; R.L. Homeycutt \& D.J. Schmidly. 2003. Taxonomic Status of White-Backed Hog-Nose Skunks, Genus Conepatus (Carnivora: Mephitidae). Journal of Mammalogy 84 (1): 159-176.

Eisenberg, J.F. \& K.H. Redford. 1999. Mammals of the Neotropics. Chicago, The University of Chicago Press, vol. $3,609 \mathrm{p}$.

Friscia, A.R.; B. van Valkenburgh \& A.R. Biknevicius. 2006. An ecomorphological analysis of extant small carnivorans. Journal of Zoology 272 (2007) 82-100.

Gonçalves, F.A.; S.Z. Cechin \& A. Bager. 2007. Predação de ni- nhos de Trachemys dorbigni (Duméril \& Bibron) (Testudines, Emydidae) no extremo Sul do Brasil. Revista Brasileira de Zoologia 24 (4): 1063-1070.

IBGE. 1978. Mapa Brasil climas - Escala 1: 5.000.000. Available online at: http://www.ibge.gov.br/home/ geociencias/default_prod.shtm [Accessed: 03/XII/2008].

IBGE. 2004. Mapa da produção de madeira em tora da silvicultura (para papel, celulose e outros fins) em nível municipal, Brasil. Available online at: http://www.ibge.gov.br/ home/presidencia/noticias/images/497_1178_761683.gif [Accessed: 04/II/2010].

IBGE. 2006. Mapa de relevo do Brasil - Escala 1: 5.000.000. Available online at: http://www.ibge.gov.br/home/ geociencias/default_prod.shtm [Accessed: 03/XII/2008].

Indrusiak, C. \& E. Eizirik. 2003. Carnívoros, p. 507-545. In: C.S. Fontana; G.A. BEncKe \& E.R. Reis (Eds). Livro vermelho da fauna ameaçada de extinção do Rio Grande do Sul. Porto Alegre, Edipucrs, 632p.

IUCN. 2010. Red list of threatened species. Version 2010.1. Available online at: http//www.iucnredlist.org [Accessed: 27/ $\mathrm{X} / 2010]$.

Leite, P.F. 2002. Contribuição ao conhecimento fitoecológico do Sul do Brasil. Ciência \& Ambiente 24: 51-73.

Link, E.C. \& D. Costa. 1984. Seletividade de inseticidas para besouros predadores em soja. Revista Centro de Ciências Rurais 14 (2): 121-128.

Montalvo, C.I.; M.E.M. Pessino \& F.C. Bagatto. 2008. Taphonomy of the bones of rodents consumed by Andean hog-nosed skunks (Conepatus chinga, Carnivora, Mephitidae) in central Argentina. Journal of Archaeological Science 35 (6) 1481-1488.

Moura, L.A. 2003. Coleópteros, p. 85-94. In: C.S. FontANA; G.A. BENCKE \& E.R. REIS (Eds). Livro vermelho da fauna ameaçada de extinção do Rio Grande do Sul. Porto Alegre, Edipucrs, 632p.

Overbeck, G.E.; S.C. Muller; A. Fidelis; J. Pfadenhauer; V.D. Pillar; C.C. Blanco; I.I. Boldrini; R. Both \& E.D. Forneck. 2007. Brazil's neglected biome: The south brazilian Campos. Perspectives in Plant Ecology, Evolution and Systematics 9: 101-116.

PARERA, A. 2002. Los mamíferos de la Argentina y la region austral de Sudamérica. Buenos Aires, El Ateneu, 453p.

Popowics, T.E. 2003. Postcanine dental form in the mustelidae and viverridae (Carnivora: Mammalia). Journal of Morphology 256 (3): 322-341.

Quadros, F.L.F. \& V.P. Pillar. 2002. Transições floresta-campo no Rio Grande do Sul. Ciência \& Ambiente 24: 109-118.

Rosa, A.O. \& J. Mauns. 2004. Atropelamento de animais silvestres na rodovia RS-040. Caderno de Pesquisa Série Biologia 16 (1): 35-42.

Sacco, T. \& B. van Valkenburgh. 2004. Ecomorphological indicators of feeding behaviour in the bears (Carnivora: Ursidae). Journal of Zoology 263 (1): 41-54. 
SBS. 2007. Zoneamento ambiental da silvicultura no RS Carta aberta a sociedade riograndense. Available online at: http://www.sbs.org.br/atualidades_single.php?id $=4484$ [Accessed: 04/II/2010].

SILVA, F. 1994. Mamíferos Silvestres do Rio Grande do Sul. Porto Alegre, Fundação Zoobotânica do Rio Grande do Sul, 243p.

Silva, P.G.; M.A.R. Garcia \& M.B. Vidal. 2008. Besouros copronecrófagos (Coleoptera: Scarabaeidae stricto sensu) coletados em ecótono natural de campo e mata em Bagé, RS. Ciência e Natura 30 (2): 71-91.

Travaini, A.; M. Delibes \& O. Ceballos. 1998. Summer foods of the Andean hog-nosed skunk (Conepatus chiga) in Patagonia. Journal of Zoology 246: 457-460.

Tumeleiro, L.K.; J. Koenemann; M.C.N. Ávila; F.R. Pandolfo \& E.V. Oliveira. 2006. Notas sobre mamíferos da região de Uruguaiana: estudo de indivíduos atropelados com infor- mações sobre a dieta e conservação. Biodiversidade Pampeana 4: 38-41.

van Gelder, G.V. 1968. The Genus Conepatus (Mammalia, Mustelidae): Variation Within a Population. American Museum Novitates 2322, 38p.

VAN VALKENBURGH, B. 1991. Interative evolution of hypercarnivory in canids (Mammalia: Carnivora): evolutionary interactions among sympatric predators. Paleobiology 17, 340-362.

Vaughan, T.A.; J.M. Ryan \& N.J. CZaplewski. 1999. Mammalogy. Philadelphia, Saunders College Publishing, 672p.

Wozencraft, W.C. 2005. Ordem Carnivora, p. 532-628. In: D.E. WILSON \& D.M. REEDER (Eds). Mammal species of the world: a taxonomic and geographic reference. Washington, D.C., Smithsonian Insgtitution Press, $3^{\text {nd }}$ ed., 2000p.

ZAR J.H. 1999. Biostatistical Analysis. New Jersey, Prentice Hall, 929p.

Submitted: 04.VII.2009; Accepted: 26.XI.2010.

Editorial responsibility: Fernando de C. Passos 